\title{
THE IMPACT OF BUSINESS SIZE AND BUSINESS TYPE ON SMALL BUSINESS INVESTMENT IN ELECTRONIC COMMERCE: A STUDY OF SWEDISH SMALL BUSINESSES
}

\author{
R.C. MacGregor \\ L. Vrazalic \\ S. Carlsson \\ D. Bunker \\ M. Magnusson ${ }^{2}$ \\ ${ }^{1}$ Department of Information Systems, \\ University of Wollongong, Australia \\ Northfields Ave \\ Wollongong NSW 2522, Australia \\ ${ }^{2}$ Department of Information Systems \\ Division for Information Technology \\ Karlstad University \\ SE-651 88 Karlstad, Sweden \\ ${ }^{3}$ School of Information Systems, Technology and Management \\ University of New South Wales \\ Sydney NSW 2052, Australia
}

\begin{abstract}
In the past, organisations relied on traditional quantitative metrics, such as Return on Investment (ROI) to make decisions when investing in technology. With the advent of electronic commerce (EC), organisations have had to rethink their investment and acquisition decisions due to the strategic nature of electronic commerce. Where ROI measures have failed, they have been replaced with a plethora of organisational driving forces. This paper focuses on the driving forces behind EC adoption by small and medium enterprises (SME's) and aims to determine the impact of organisational factors such as size and type of business on EC acquisition criteria. The results of a research study carried out in Sweden are presented and suggest that there exist high levels of significance between the size of the business and customer demand, reduced costs, developing new markets and improvement to marketing as driving forces, and the type of business and customer demand, pressure from competition, increased sales and improvement of relationship with business partners as driving forces for EC adoption.
\end{abstract}

\section{INTRODUCTION}

Prior to the advent of electronic commerce (EC) organisations utilised technology to enforce specific products and product boundaries. The products themselves were tangible, requiring physical inputs and processes that could be easily evaluated. Boundaries around these products were defined by the products themselves and maintained within the operational level of the organisation such that organisational strategies were fixed and controllable. The technology used to support these products was standalone and, like the products it supported, could be evaluated by aggregated financial outcomes that related to the objectives of the organisation as a whole. As a result, decisions to invest in technology involved an examination of the return on investment (ROI), a measure that was housed within strict strategic boundaries in the organisation.

The advent of EC has not only radically altered the day-to-day procedures of the organisation (Kuljis et al 1998) but has also altered the use of technology within the organisation (Fuller 2000; Kendall \& Kendall 2001). As the use of technology has changed, so have the corresponding investment decision making processes. Instead of physical products and services, and their operational boundaries, other organisational factors have had an influence on strategic investment decision making. These changes have not only affected large organisations, but have had an impact on small to medium enterprises (SME's) as well. The aim of this paper is to examine the impact of organisational factors, including size and type of business, on the driving forces behind EC acquisition by SME's.

This paper begins by examining some of the changes brought about by the advent of EC, in particular changes to the metrics used by organisations when considering investment in EC technology. The paper then discusses the nature of SME's, in particular their approach to acquisition, investment and use of EC technology. Finally, the paper presents a study of 118 Swedish SME's which investigated the major reasons for the adoption of EC. The study also endeavoured to ascertain whether organisational factors such as the size of the business and the type of business were associated with driving forces behind the adoption of EC.

\section{METRICS ADOPTED BY ORGANISATIONS WHEN CONSIDERING EC TECHNOLOGY}

As already suggested, prior to the advent of EC, technology was designed to embody existing organisational values and practices, power relationships and conventions, where retail and financial strategies were fixed and controllable. Organisations utilised technology to enforce the use of specific products and product boundaries. 
This was achievable by limiting the number and types of products and by placing the boundaries within the operational levels of the organisation. Factors that might be termed informal social ties (customers, competitors, environmental trends) were 'shadows' to the formal organisation. The focus, instead, was on computerising procedures to achieve low-level operational competence. The role of technology was simply to increase efficiency, within the product boundaries, at a procedural level (Schneider 1999), while decisions to invest in technology were primarily concerned with improvements to organisational efficiency and effectiveness. They were carried out in terms of strict strategic boundaries and were adjudged on rigid internal perspectives. An organisation considering the adoption of technology examined the ROI of such technology where that ROI was housed within a pre-stated set of strategic guidelines.

A number of authors (Kollman 1998; Dugan 1999; Hlava 1999; Wilder 1999; Violino 2000a; Cameron 2000) have argued that with the advent of EC, traditional ROI measurements have become obsolete or invalid. They suggest that ROI is incapable of accounting for hidden costs and intangible strategic benefits, and that it cannot keep pace with the need to constantly adjust due to the fast pace of information technology (IT) development. Instead, there have been diverse attempts to apply different forms of evaluation methods and calculations in order to gauge the payback of IT investments. Indeed, Wilder (1999) reports that many organisations are "tossing out conventional thinking about the need for a return on investment and focusing on how the initiatives advance their overall business strategy, whether it's to improve customer satisfaction, increase brand awareness, or open new sales channels". Organisations have begun to rely on in-house, as well as off-the-shelf products for this purpose (Moozakis \& Lewis 2000). Some of the methods utilised include identifying sources of sales revenue generated through and attributable to e-commerce (Violino 2000a), customer satisfaction surveys (Violino 2000b), measuring the IT performance of an e-commerce website as a whole, operational cost savings, observing customers' surfing and online purchasing habits to expand marketing strategies, determining the revenues generated during off-business hours, counting online transactions and the number of online visitors (Lewis 2000), as well as benchmarking against competitors. Where these methods fail, they are replaced by the instincts and experience of managers and decision makers (Violino 2000a). Not surprisingly, some organisations have begun viewing e-commerce outlays as absolutely necessary, regardless of cost, in order to remain competitive. Cameron (2000) further confirms the abandonment of formal ROI calculations by stating that IT projects and investments can be justified for any number of reasons, without ever measuring any form of ROI, highlighting the importance placed on e-commerce in the modern organisation.

A number of reasons have been put forward for the inefficiency of ROI as a measure of EC investment. Wilder (1999) suggests that fundamental to the changes brought about by EC is the need for organisations to realise that as the line between product and product boundaries has become blurred, so too has the line between the operational and strategic roles of technology. Indeed, as technology pervades the whole financial structure of organisations, such that web strategies become inexorably linked with overall business strategies (Lederer et al 1997), it needs to be examined from a strategic standpoint rather than as just another technological adjunct. Norman and Zafar (1999) suggest that organisations need to clearly examine and articulate their business strategies in terms of e-commerce.

Brynjolfsson and Hitt (1998) suggest that today investment in EC cannot exist without investment in organisational change and a re-examination of the products and the product boundaries. Chircu and Kauffman (2000) add that there has been a shift from technology that supports products to technology which is tailored to the customer. For the organisation, the 'shadows' of the past (customers, competitors, environmental trends) have become legitimate formal structures, pushing aside old organisational hierarchies. The implications of this development have led many organisations, including SME's which will be discussed next, to re-examine their IT acquisition and investment strategies, in particular those relating to EC adoption.

\section{THE NATURE OF SMALL BUSINESSES}

The special circumstances of small business have been the topic of many government committee findings as well as research initiatives. Barnett and Mackness (1983) suggest that small businesses should not be thought of as miniature versions of large businesses, but quite unique in their own right. Small business tends to be more risky than its larger counterpart (Brigham \& Smith 1967; Walker 1975), it is subject to higher failure rates (Klatt 1973; Cochran 1981) and tends to keep less adequate records (Markland 1974; Rotch 1987).

Reynolds, Savage and Williams (1994) provide the following summary of features of small business generally not shared by larger organisations:

- A small management team

- Strong owner influence

- Multi-functional management

- A close and loyal work team

- Centralised power and control 
- Lack of specialist staff

- Informal and inadequate planning and control systems

- Lack of promotable staff

- Lack of control over the business environment

- Limited ability to obtain finance

- Labour intensive work

- Limited process and product technology

- Narrow product/service range, limited market share and heavy reliance on few customers

- Intuitive rather than rational decisions

- Reactive rather than innovative responses to change

- Personal rather than tasks oriented leadership

- Education, experience and skills practical but narrow

- Low employee turnover

- Product dedication rather than customer orientation

- Reluctance to take risks

- Management heavily swayed by the owner's personal idiosyncrasies

- Strong desire for independence

- Intrusion of family interests

In line with general views concerning small business, the acquisition and subsequent use of computer technology in the small business environment cannot simply be considered a miniaturised version of the larger organisation. Clearly, many of the features gleaned from studies of larger businesses can be applied to small business. However, the nature of small business operations presents a variety of factors which must be considered when computer technology is acquired in the small business environment. It is now appropriate to look at EC acquisition in light of the research carried out on SME's.

\section{ACQUISITION OF EC BY SME's}

There have been a number of studies that have examined the involvement in EC by SME's. Many of these studies (Cragg \& King 1993; Thong et al 1996; Kollman 1998) have concentrated on the implementation and post-implementation phases of technology use, however recent literature has begun to see the importance of the pre-acquisition decision making process.

In a study of 308 CEO's, Reimenshcneider and Mykytyn (2000) nominated a variety of reasons, which they termed 'Most Important Things' that prompted SME's into the adoption of EC. These included reduction of costs, increased productivity, faster feedback of information and access to customers. A similar study of the Asia Pacific region by PriceWaterhouseCoopers (1999) suggested factors such as improved customer service, customer information exchange, improved competitiveness, access to international markets, increased revenue, attracting new investment, as reasons put forward by SME's for their adoption of EC. Similar studies by Fuller (2000) and Kendall (2000) have provided comparable lists of reasons for the adoption of EC by SME's.

Not only does the literature seem to support the views of authors such as Wilder (1999), Violino (2000a), Cameron (2000), that there are alternatives to simple ROI when EC is considered, recent studies (Thong 1999; McDonagh \& Prothero 2000; Korchak \& Rodman 2001) suggest that these alternatives are affected by factors such as size of business and the type of business. Indeed, in a study of SME's in the US, Korchak and Rodman (2001) found that $29 \%$ of SME's with a staff number above 20 were using EC in their day-to-day business activities compared to $13 \%$ for organisations with staff levels below 20 . These figures are comparable to a study carried out in Australia by the Department of Communication Information Technology (2000) which found that $28 \%$ of SME's with a staff greater than 20 were using EC, as compared to $17 \%$ of those with a staff level below 20. The Australian study also examined the respondent group across business type and found that $14 \%$ of industrial SME's were using EC in their day-to-day activities as compared to $31 \%$ of those SME's involved in the service sector. A research study, which investigated the impact of these organisational factors on driving forces behind EC adoption in Swedish SME's, will be presented next.

\section{SURVEY INSTRUMENT}

A questionnaire was developed for SME managers. A series of factors termed 'driving forces for the adoption of EC' were developed. The inclusion and exclusion of factors was based on previous studies, in particular those carried out by PriceWaterhouseCoopers (1999) and Reimenschneider and Mykytyn (2000). Only those factors 
which were reported as having a greater than $50 \%$ response as important were included in the survey instrument. The list of factors included in the questionnaire were:

- customer demand

- pressure by competition

- pressure by suppliers

- reduced cost

- improvement to customer services

- improvement to lead time

- increased sales

- increased sales improvement to internal efficiency

- improved relationships with business partners

- development of new markets

- improved competitiveness

- improved marketing

- greater control of the business

Respondents were asked to rate each of these factors as pertaining to their adoption EC across a 5 point Lickert scale where 1 indicates that the factor was unimportant to the decision to adopt EC, 2 indicates little importance to the decision to adopt EC, 3 indicates some importance to the decision to adopt EC, 4 indicates the factor was quite important to the decision to adopt EC and 5 indicates it was of greatest importance to the decision to adopt EC. Respondents were also asked the number of employees in the organisation (none (self-employed); 1 to $9 ; 10$ to $19 ; 20$ to 49 ; more than 50 ) as well as the type of business (industrial, service, retail, finance). The questionnaires were distributed to SME's around three regional areas of Sweden and SME's that are members of the chamber of commerce.

\section{ANALYSIS OF RESPONSES}

A total of 1170 questionnaires were distributed. Responses were obtained from 260 SME organisations giving a response rate of $22.4 \%$. Of the 260 responses, 118 indicated that they were using EC in their day-to-day business activities. Tables 1 and 2 provide a description of the respondent group, while Table 3 provides the overall responses for the major driving forces behind the adoption of EC. Some respondents did not complete the questionnaire fully. This was taken into account in the statistical analysis.

Table 1

Total respondents

EC users

37

Number of Employees

$\begin{array}{ccccc}0 & 1-9 & 10-19 & 20-49 & >50 \\ 37 & 131 & 36 & 27 & 26 \\ 9 & 49 & 21 & 19 & 20\end{array}$

Table 2

Type of Business

Total respondents Industrial Service

59

95

31

49

$\begin{array}{cc}\text { Retail } & \text { Finance } \\ 48 & 54 \\ 19 & 5\end{array}$


Table 3

Factors which were the major driving forces behind the adoption of EC

\begin{tabular}{|c|c|c|c|c|c|}
\hline & $\begin{array}{c}\text { No } \\
\text { importance }\end{array}$ & $\begin{array}{c}\text { Little } \\
\text { importance }\end{array}$ & $\begin{array}{c}\text { Some } \\
\text { importance }\end{array}$ & $\begin{array}{c}\text { Very } \\
\text { important }\end{array}$ & $\begin{array}{l}\text { Greatest } \\
\text { importance }\end{array}$ \\
\hline Customer demand & 48 & 25 & 20 & 19 & 6 \\
\hline Pressure by competition & 36 & 20 & 32 & 19 & 9 \\
\hline Pressure by suppliers & 57 & 23 & 19 & 13 & 3 \\
\hline Reduced cost & 13 & 12 & 28 & 37 & 27 \\
\hline $\begin{array}{l}\text { Improved customer } \\
\text { services }\end{array}$ & 6 & 1 & 16 & 43 & 52 \\
\hline $\begin{array}{l}\text { Improvement to lead } \\
\text { time }\end{array}$ & 29 & 14 & 23 & 30 & 19 \\
\hline Increased sales & 17 & 13 & 35 & 25 & 26 \\
\hline $\begin{array}{l}\text { New markets } \\
\text { development }\end{array}$ & 18 & 15 & 21 & 33 & 30 \\
\hline $\begin{array}{l}\text { Improved } \\
\text { competitiveness }\end{array}$ & 13 & 5 & 18 & 41 & 39 \\
\hline Improved marketing & 24 & 8 & 21 & 30 & 33 \\
\hline $\begin{array}{l}\text { Greater control of } \\
\text { business }\end{array}$ & 25 & 16 & 28 & 29 & 19 \\
\hline $\begin{array}{l}\text { Improved relationships } \\
\text { with business partners }\end{array}$ & 16 & 11 & 32 & 39 & 19 \\
\hline
\end{tabular}

A series of chi-square tests were carried out to determine whether the number of employees or the type of business were associated with the rating of factors behind the adoption of EC. For brevity, only the significant data will be shown.

Tables 4 to 7 show that the number of employees was significantly associated with the rating of the following EC adoption factors - customer demand, reduced costs, possibility of new markets and improved marketing.

\section{Table 4}

Rating of the importance of customer demand as a criteria for the adoption of EC

$\begin{array}{lccccc}\text { No of employees } & \begin{array}{c}\text { No } \\ \text { importance }\end{array} & \begin{array}{c}\text { Little } \\ \text { importance }\end{array} & \begin{array}{c}\text { Some } \\ \text { importance }\end{array} & \begin{array}{c}\text { Very } \\ \text { important }\end{array} & \begin{array}{c}\text { Greatest } \\ \text { importance }\end{array} \\ 0 & 5 & 1 & 2 & 1 & 0 \\ 1-9 & 27 & 10 & 5 & 5 & 2 \\ 10-19 & 5 & 9 & 2 & 5 & 0 \\ 20-49 & 5 & 3 & 6 & 4 & 1 \\ >50 & 6 & 2 & 5 & 4 & 3 \\ (\mathrm{p}<.05) & & & & & \end{array}$


Table 5

Rating of the importance of reduced costs as a criteria for the adoption of EC

$\begin{array}{lccccc}\text { No of employees } & \begin{array}{c}\text { No } \\ \text { importance }\end{array} & \begin{array}{c}\text { Little } \\ \text { importance }\end{array} & \begin{array}{c}\text { Some } \\ \text { importance }\end{array} & \begin{array}{c}\text { Very } \\ \text { important }\end{array} & \begin{array}{c}\text { Greatest } \\ \text { importance }\end{array} \\ 0 & 5 & 0 & 1 & 2 & 1 \\ 1-9 & 4 & 9 & 13 & 11 & 11 \\ 10-19 & 2 & 0 & 2 & 10 & 7 \\ 20-49 & 2 & 2 & 6 & 6 & 3 \\ >50 & 0 & 1 & 6 & 8 & 5\end{array}$

\section{Table 6}

Rating of the importance of developing new markets as a criteria for the adoption of EC

$\begin{array}{lccccc}\text { No of employees } & \begin{array}{c}\text { No } \\ \text { importance }\end{array} & \begin{array}{c}\text { Little } \\ \text { importance }\end{array} & \begin{array}{c}\text { Some } \\ \text { importance }\end{array} & \begin{array}{c}\text { Very } \\ \text { important }\end{array} & \begin{array}{c}\text { Greatest } \\ \text { importance }\end{array} \\ 0 & 4 & 1 & 0 & 3 & 1 \\ 1-9 & 8 & 3 & 9 & 8 & 21 \\ 10-19 & 1 & 1 & 6 & 8 & 5 \\ 20-49 & 1 & 4 & 5 & 8 & 1 \\ >50 & 4 & 6 & 1 & 6 & 2\end{array}$

Table 7

Rating of the importance of improvement to marketing as a criteria for the adoption of EC

$\begin{array}{lccccc}\text { No of employees } & \begin{array}{c}\text { No } \\ \text { importance }\end{array} & \begin{array}{c}\text { Little } \\ \text { importance }\end{array} & \begin{array}{c}\text { Some } \\ \text { importance }\end{array} & \begin{array}{c}\text { Very } \\ \text { important }\end{array} & \begin{array}{c}\text { Greatest } \\ \text { importance }\end{array} \\ 0 & 4 & 1 & 1 & 2 & 1 \\ 1-9 & 6 & 1 & 8 & 11 & 22 \\ 10-19 & 0 & 0 & 2 & 11 & 8 \\ 20-49 & 1 & 1 & 5 & 8 & 4 \\ >50 & 2 & 2 & 2 & 9 & 4\end{array}$

The data was also examined to determine whether the type of business was significantly associated with the rating of any of the EC adoption criteria. Tables 8 to 11 show that the type of business was significantly associated with the rating of the following EC adoption factors: customer demand, pressure from competition, increased sales and improvement of relationships with business partners.

\section{Table 8}

Rating of the importance of customer demand as a criteria for the adoption of EC

$\begin{array}{lccccc}\text { Type of business } & \begin{array}{c}\text { No } \\ \text { importance }\end{array} & \begin{array}{c}\text { Little } \\ \text { importance }\end{array} & \begin{array}{c}\text { Some } \\ \text { importance }\end{array} & \begin{array}{c}\text { Very } \\ \text { important }\end{array} & \begin{array}{c}\text { Greatest } \\ \text { importance }\end{array} \\ \text { Industrial } & 13 & 5 & 5 & 5 & 3 \\ \text { Service } & 21 & 12 & 7 & 9 & 0 \\ \text { Retail } & 9 & 5 & 4 & 1 & 0 \\ \text { Finance } & 0 & 1 & 1 & 1 & 2\end{array}$


Table 9

Rating of the importance of pressure from competition as a criteria for the adoption of EC

$\begin{array}{lccccc}\text { Type of business } & \begin{array}{c}\text { No } \\ \text { importance }\end{array} & \begin{array}{c}\text { Little } \\ \text { importance }\end{array} & \begin{array}{c}\text { Some } \\ \text { importance }\end{array} & \begin{array}{c}\text { Very } \\ \text { important }\end{array} & \begin{array}{c}\text { Greatest } \\ \text { importance }\end{array} \\ \text { Industrial } & 8 & 7 & 9 & 5 & 2 \\ \text { Service } & 16 & 9 & 14 & 8 & 1 \\ \text { Retail } & 8 & 3 & 5 & 3 & 0 \\ \text { Finance } & 0 & 0 & 1 & 0 & 4\end{array}$

Table 10

Rating of the importance of increased sales as a criteria for the adoption of EC

$\begin{array}{lccccc}\text { Type of business } & \begin{array}{c}\text { No } \\ \text { importance }\end{array} & \begin{array}{c}\text { Little } \\ \text { importance }\end{array} & \begin{array}{c}\text { Some } \\ \text { importance }\end{array} & \begin{array}{c}\text { Very } \\ \text { important }\end{array} & \begin{array}{c}\text { Greatest } \\ \text { importance }\end{array} \\ \text { Industrial } & 2 & 3 & 13 & 9 & 5 \\ \text { Service } & 10 & 8 & 14 & 10 & 6 \\ \text { Retail } & 1 & 1 & 6 & 3 & 8 \\ \text { Finance } & 1 & 0 & 0 & 0 & 4\end{array}$

$(\mathrm{p}<.05)$

Table 11

Rating of the importance of improvement of relationships with business partmers as a criteria for the

$\begin{array}{lccccc}\text { Type of business } & \begin{array}{c}\text { No } \\ \text { importance }\end{array} & \begin{array}{c}\text { adoption of EC } \\ \text { Little } \\ \text { importance }\end{array} & \begin{array}{c}\text { Some } \\ \text { importance }\end{array} & \begin{array}{c}\text { Very } \\ \text { important }\end{array} & \begin{array}{c}\text { Greatest } \\ \text { importance }\end{array} \\ \text { Industrial } & 2 & 0 & 11 & 12 & 6 \\ \text { Service } & 8 & 6 & 14 & 15 & 5 \\ \text { Retail } & 1 & 3 & 6 & 3 & 6 \\ \text { Finance } & 3 & 0 & 0 & 1 & 1\end{array}$

\section{DISCUSSION}

Before examining the data in detail, it is interesting to note that of the 260 respondents, only 118 (45.4\%) indicated that they are using EC in their day-to-day business activities. This finding will be the subject of a study to be produced by the authors. Furthermore, an examination of Table 1 shows that those respondents who had a staff level above 10 were far more likely to adopt EC than those with less than 10 employees. This data is in accord with the studies carried out by Department of Communication Information Technology (2000) and Korchak and Rodman (2001).

A number of authors and studies (Wilder 1999; PriceWaterhouseCoopers 1999; Violino 2000b; Reimenschneider \& Mykytyn 2000) have suggested that factors other than strict ROI are being used by SME's as criteria to be considered for the adoption of EC. A closer examination of Table 3 would tend to support this, at least amongst the respondent group. While reduction of cost was seen as important as a criteria for the adoption of EC, by far the strongest reasons appear to be improvements to customer services, improvements to internal efficiency and improvements to organisational competitiveness. While these figures do not actually reject ROI, they suggest that for SME's, ROI is only one of several factors that need to be taken into consideration when adopting EC.

Based on recent studies (Thong 1999; McDonagh \& Prothero 2000; Korchak \& Rodman 2000) which suggested that the size of the organisation had an effect upon the decision making processes surrounding the adoption of $\mathrm{EC}$, the data was examined to determine whether the number of employees was associated with the rating of any of the factors behind EC adoption. The figures presented in tables 4 to 7 suggest that at least for some factors, there is a significant association to the size of the organisation.

An examination of Table 4 shows that for organisations with less than 10 employees, demand from customers was of little or no importance when EC was being considered. For those organisations with larger employee levels, the demand from customers had some importance in the decision making process. Table 5, on the other 
hand, compares the rating of the reduction of cost as a factor behind the adoption of EC, with the size of the organisation. As the data indicates, organisations with staff levels greater than 10 tended to place a higher importance on cost reduction than those organisations with a small staff group. Indeed, over $50 \%$ of those organisations who had no staff placed no importance on the reduction in cost as a criteria for the adoption of EC. An examination of Table 6 shows that medium sized SME's (I to 20 employees) placed a higher level of importance on the use of EC to attract new markets than those organisations whose staffing level was greater than 20. Finally, a closer look at Table 7 indicates that, with the exception of single person organisations, all other respondents placed a great deal of importance on improvement to marketing through the adoption of EC. Studies by PriceWaterhouseCoopers (1999) and Department of Communication Information Technology (2000) suggested that the type of business has a direct bearing upon the decision making process surrounding the adoption of EC. The data presented in tables 8 to 11 shows that the rating of at least some factors associated with the adoption of EC are significantly associated with the type of business of the respondent. Demand from customers and pressure from competition were rated as being important only by finance organisations. As can be seen in Table 8, with the exception of those businesses involved with finance, little importance was placed on the demand of customers in the adoption of EC, while Table 9, indicating that the finance sector placed the most importance on pressure from competition, supports the findings of Wilder (1999). An examination of table 10 shows that all respondents, with the exception of service organisations, placed a high emphasis on increased sales as a criterion for the adoption of EC. Finally, Table 11 also shows that all groups, except financial sector organisations, placed a moderately high level of importance on improving business relations with partners. $60 \%$ of the financial sector saw no importance in this factor.

\section{CONCLUSION}

The advent of EC has made it necessary for SME's to radically re-think their priorities when making decisions as to whether to adopt the technology into their organisation. Since EC has such wide ranging effects on the organisation, simple ROI no longer suffices as the only justifying metric through which decisions can be made. Not only is there a need to re-think the metrics involved in the decision making process, there is also convincing evidence that organisational factors, including the number of employees and type of business, have a strong bearing on the importance of many of the driving forces behind EC.

The results of this study have led to two conclusions. First, it supports the findings of similar research indicating that SME's have already begun to think beyond simple ROI as a sole mechanism to decide whether EC should be adopted. Secondly, factors such as size of organisation and the type of business, appear to have some bearing upon the importance placed on certain factors when these decisions are being made.

\section{ACKNOWLEDGEMENTS}

The authors would like to express their appreciation to Sara Berggren and Anette Stjärnkvist for their help in distributing and collating the questionnaires.

\section{REFERENCES}

Barnett, R.R. \& Mackness, J.R. (1983) "An Action Research Study of Small Firm Management", Journal of Applied Systems Analysis, Vol 10, pp $63-83$.

Brigham, E.F. \& Smith, K.V. (1967) "The Cost of Capital to the Small Firm", The Engineering Economist, Vol 13 No $1, \mathrm{pp} 1-26$.

Brynjolfsson, E. \& Hitt, L.M. (1998) "Beyond the Productivity Paradox", Communications of the ACM, Vol 41 No 8 , pp $49-55$.

Cameron, P. (2000) "Measuring Up", CMA Management, Vol 74 No 2, pp $26-28$.

Chircu, A.M \& Kauffman, R.J. (2000) "Limits to value in Electronic Commerce-Related IT Investments", Journal of Management Information Systems, Vol 17 No 2, pp $59-80$.

Cochran, A.B. (1981) "Small Business Mortality Rates: A Review of the Literature", Journal of Small Business Management, Vol 19 No 4, pp 50 - 59.

Cragg, P.B. \& King, M. (1993) "Small Firm Computing: Motivators and Inhibitors", MIS Quarterly, Vol 17 No $1, \mathrm{pp} 47-60$.

Department of Communication Information Technology, Australia (2000) Taking the Plunge, $49 \mathrm{pp}$

Dugan, S. (1999) "The Revenue Factors: Strategies for Maximizing E-Commerce Success", Infoworld, Vol 21 No $40, \mathrm{pp} 70-72$.

Fuller, T. (2000) "The Small Business Guide to the Internet: A Practical Approach to Going Online", International Small Business Journal, Vol 19 No 1, pp $105-107$ 
Hlava, M.M.K. (1999) "Expanding partnerships for Small-and Medium-Sized Enterprises (SME's) Needed: The Right Kind of Support", Bulletin of the American Society of Information Science, Vol 25 No 5, pp 7-9.

Kendall, K.E. (2000) "E-Commerce Aesthetics: E-Commerce for E-Commerce' Sake", Information Resources Management Journal, Vol 13 No 3, pp 3-4.

Kendall, J.E. \& Kendall, K.E. (2001) "A Paradoxically Peaceful Coexistence Between Commerce and Ecommerce", Journal of Information Technology Theory and Application, Vol 3 No 4, pp 1 - 6.

Klatt, L.A. (1973) Small Business Management: Essential in Entrepreneurship, Wadsworth, CA

Kollman, T. (1998) "Marketing for Electronic Market Places - The Relevance of Two 'Critical Points of Success", Electronic Markets, Vol 8 No 3, pp 36-39.

Korchak, R. \& Rodman, R. (2001) "eBusiness Adoption Among US Small Manufacturers and the Role of Manufacturing Extension", Economic Development Review, Vol 17 No 3, pp $20-25$.

Kuljis, J, Macredie, R. \& Paul, R.J. (1998) "Information Gathering Problems in Multinational Banking", Journal of Strategic Information Systems, Vol 7, pp $233-245$.

Lederer, A.L., Mirchandani, D.A. \& Sims, K. (1997) "The Link Between Information Strategy and Electronic Commerce", Journal of Organisational Computing and Electronic Commerce, Vol 7 No 1, pp $17-34$.

Lewis, D. (2000) "Pressure Mounts To Gauge E-Biz ROI", InternetWeek, URL http://www.internetweek.com/transformation2000/issues/roi.htm.

McDonagh, P. \& Prothero, A. (2000) "Eurolicking and the Irish SME: Prepared for E-Commerce and the Single Currency", Irish Marketing Review, Vol 13 No 1, pp 21 - 33.

Markland, R.E. (1974) "The Role of the Computer in Small Business Management", Journal of Small Business Management, Vol 12 No 1, pp $21-26$.

Moozakis, C. \& Lewis, D. (2000) "Enterprises Tailor ROI To E-Business", InternetWeek, URL http://www.internetweek.com/netresults/net121800.htm.

Norman, J.D. \& Zafar, S. (1999) "E-Analytics: Science and Art", Banking Strategies, Vol 75 No 2, pp 6-12.

PriceWaterhouseCoopers (1999) SME Electronic Commerce Study Final Report, 37pp

Reimenschneider, C.K. \& Mykytyn, P.P.jr (2000) "What Small Business Executives have Learned About Managing Information Technology", Information \& Management, Vol 37, pp 257 - 267.

Reynolds, W., Savage, W. \& Williams, A. (1994) Your own business: A Practical guide to success, ITP.

Rotch, W. (1987) Management of small enterprises: Cases and Readings, University of Virginia Press.

Schneider, P. (1999) “Australia Unbound", CIO, Vol 12 No 16, pp 40 - 45.

Thong, J.Y.L., Yap, C.S, \& Raman, K.S. (1996) "Top Management Support, External Expertise and Information Systems Implementation in Small Business", Information Systems Research, Vol 7 No 2, pp 248 - 267.

Violino, B. (2000a) "IT Excellence 500", Internetweek, No 754, pp $48-62$.

Violino, B. (2000b) "Payback Time For E-Business", Internetweek, Special Issue 811.

Walker, E.W. (1975) "Investment and Capital Structure Decision Making in Small Business" in Walker, E.W. (ed) The Dynamic Small Firm: Selected Readings, Austin Press, Texas.

Wilder, C. (1999) 'ROI: E-business Strategic Investment", Informationweek, No 735, pp 48 - 56. 